\title{
COMPARISON OF BANKRUPTCY PREDICTION MODELS ANALYSIS (ALTMAN, SPRINGATE, GROVER, OHLSON AND ZMIJEWSKI) ON PT. ASURANSI HARTA AMAN PRATAMA, TBK.
}

\author{
Dyah Puspitasari Sunaryo Putri \\ University of Pamulang \\ dyah.puspita80@gmail.com
}

\begin{abstract}
PT. Asuransi Harta Aman Pratama, Tbk. is a financial services company which is specialized in general insurance. This research is conducted based on five annual reports spanned from 2012 to 2016 which are independently audited. This study, therefore, aims to compare with five models bankruptcy predictions; the Altman, Springate, Grover, Ohlson and Zmijewski. This study uses a quantitative research approach, using the financial statements data of PT. Asuransi Harta Aman Pratama, Tbk. which also has been published in BEI. This paper analyze the prediction of every method using analysis of variance. The result of this analysis show the differences between the applied models.
\end{abstract}

Keywords: The Altman, Springate, Grover, Ohlson, Zmijewski

\section{INTRODUCTION}

Finance and accounting are complex domains in which multiple components often interact, making them active areas of study for uncovering the challenges posed by the domain complexity. In addition, the challenge of accurate assessment of business failure prediction under scenarios of financial crisis is known to be complicated. A particularly disruptive case is when the markets' volatility and unpredictability introduce great uncertainty. In such scenarios, credit risk is a primary concern for banks and investors that screen firms and monitor their efforts. As a consequence, there is a great need for accurate analytical tools that are able to predict corporate bankruptcy among the companies in which investors are willing to place their investments, along with the design of early warning systems (Antunes, Francisco et al, 2017)
The bankruptcy or predictive models are the early warning systems based on an analysis of selected indicators that have the ability to indicate a threat in the company's financial health. The models are based on the assumption that a few years before the bankruptcy it is possible to identify symptoms of future problems, which are characteristic for these companies (Braunová \& Jantošová, 2015). They could detect the indicators of potential future problems whose early solution can prevent serious consequences for the company (Daniela, Rybárová, et al, 2016).

Based on study Gamayuni (2011) the cause of bankruptcy can come from the internal and the external factors of the company. If the company goes bankrupt, of course there are some parties that will be harmed the parties who have interests against companies such as investors and 
creditors (Adriana, et al, 2012). To minimize the risk of bankruptcy, a tool or prediction model can be used to predict the presence or absence of potential bankruptcy of the company. Several studies comparing three models of Altman Z-score model, Zmijewski model and Springate model have different conclusion in term of the best prediction models (Putra, Ivan Gumilar Sambas and Rahma Septiani, 2016). In addition to the three prediction models of bankruptcy, there are several other models, Ohlson model and Grover model.

The General Insurance Association of Indonesia (AAUI) recorded a gross premium of the general insurance industry in 2015 of $\mathrm{Rp} 58.9$ trillion, or increased by 6.7 percent from the previous year. The increment was much less than that of year 2014 which reached 17.9 percent with gross premium bookings worth $\mathrm{Rp} 55,2$ trillion

(http://ekonomi.metrotvnews.com, 2016).

PT. Asuransi Harta Aman Pratama, Tbk. is a going public financial services company which specialized in general insurance. In 2015, this company had a decline in profit due to the drastic weakening in insurance growth nationwide. In 2016 there was no significant significant increase as illustrated in Figure 1

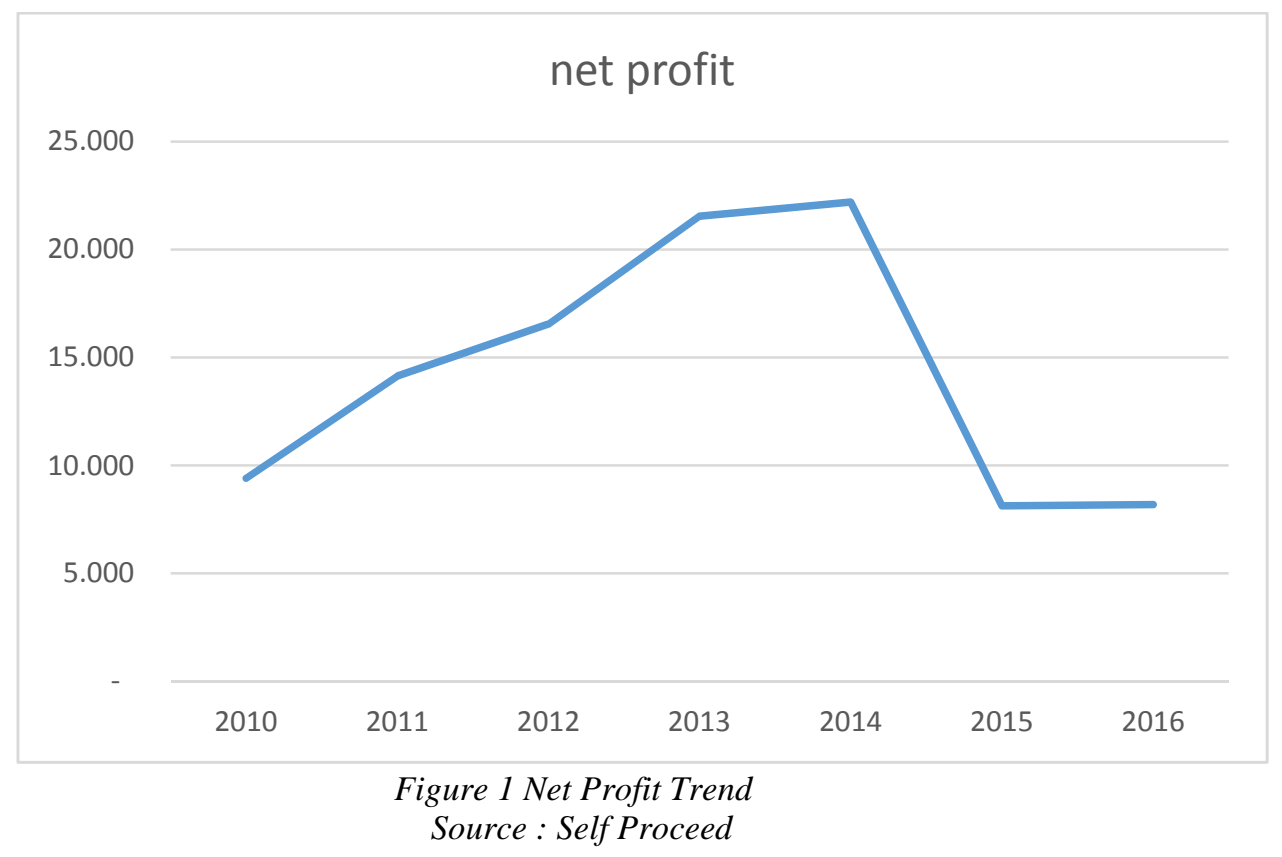

Based on the above description in this study, the authors analyzed the effectiveness of the implementation of five prediction models of bankruptcy namely Altman Z-score, Springate, Ohlson, Zmijewski and Grover using the financial record of PT. Asuransi Harta Aman Pratama, Tbk.

\subsection{Formulation of The Problem}

The following is the problem formulation in this study:
1. How do the five prediction models of bankruptcy namely Altman Zscore, Springate, Ohlson, Zmijewski and Grover forecast the actual condition of PT. Asuransi Harta Aman Pratama, Tbk. Period 2012 - 2016 ?

2. Use analysis of variance, Is there any difference analysis of the prediction using Altman Z-score, Springate, Ohlson, Zmijewski and Grover models in the bankruptcy 
prediction of PT. Asuransi Harta Aman Pratama, Tbk. in the period of $2012-2016$ ?

\section{LITERATURE REVIEW}

\subsection{Bankruptcy}

Bankruptcy is a very severe liquidity hazard situation that a company is no longer be able to run the operation properly; while financial distress is a financial difficulty or liquidity that may lead to bankruptcy. A bankruptcy statement is a legal precedent when creditors or other parties file a bankruptcy suit. The bankruptcy analysis is conducted to attain an early warning of bankruptcy. The earlier signs of bankruptcy are known, the better for the management because they can make improvements. The creditor and shareholder can anticipate a variety of bad possibilities (Kusumo, Willyanto Kartiko, 2002).

Bankruptcy could occur swiftly to companies in countries that are experiencing economic difficulties, because economic destitution will trigger the rapid bankruptcy of companies that may have been bankrupt. There are some managerial and operational signs or indicators that could arise when the company will go bankrupt (Suwarsono, 2000).

\subsection{Models of Bankruptcy Prediction}

The following are five models of bankruptcy prediction which will be used in these study.

\subsubsection{Altman - Z Score Model}

The most well-known quantitative model for predicting bankruptcy is Altman's Z-score, which was developed in 1968 by Edward I. Altman, professor at New York's Stern School of Business to measure the distance to default of manufacturing companies. The Z-score is a multiple discriminant analysis which combines ratios in a multivariate context. By taking a sample of 66 companies, Altman examined a list of twenty two possible ratios and finally chose five after numerous tests for the discriminant function (El Khoury, Rim, and Al Beaïno, Roy, 2014).

Altman (1968) defined his distress function into:

$\mathrm{Z}=1.2 \mathrm{X}_{1}+1.4 \mathrm{X}_{2}+3.3 \mathrm{X}_{3}+0.6 \mathrm{X}_{4}+$ $\mathrm{X} 5$

Where:

$\mathrm{X}_{1}=$ working capital/total assets;

$\mathrm{X}_{2}=$ retained earnings/total assets;

$\mathrm{X}_{3}=$ earnings before interest and taxes/total assets;

$\mathrm{X}_{4}=$ market value equity/ total debt; and $\mathrm{X} 5=$ annual sales /total assets.

From the calculation of Altman Model (1968) Z-Score is obtained values which are divided into three categories as follows:

1. If the value $Z>2.99$, the company is not going bankrupt.

2. If the value of $1.80 \leq Z \leq 2.99$, it means the gray area category where the company has financial problems, although not as serious as the problems of companies that went bankrupt.

3. If the value of $Z<1.80$, it indicate the company in a state of bankruptcy.

\subsubsection{Springate's Model}

Springate's model developed in 1978. It uses four variables and a twolevel system for estimations of the company's status for prediction of bankruptcy. The two levels are "Bankrupt" and "No Bankrupt" (I. Popchev and I. Radeva, 2003).

Just as the steps undertaken by Altman (1968) in study, Springate (1978) originally collected popular financial ratios that could be used to predict financial distress. Unlike the 22 initial ratios collected by the Altman, the Springate only collects an initial ratio of 19 numbers. Later, having the same test as Altman (1968), Springate chose 4 credible ratios to predict financial distress. The Springate model (1978) from the selected 4 ratios are as follows: 
$Z=1.03 X_{1}+3.07 X_{2}+0.66 X_{3}+0.4$

$\mathrm{X}_{4}$

Where:

$\mathrm{X}_{1}=$ Working Capital / Total Assets

$\mathrm{X}_{2}=$ retained earnings/total assets;

$\mathrm{X}_{3}=$ earnings before interest and taxes/total assets;

$\mathrm{X}_{4}=$ market value equity/ total debt; and

$\mathrm{X}_{5}=$ annual sales /total assets.

The criteria of the scores obtained by a company from this Springate prediction model exceeded 0.862 , by which the firm is predicted to have no potential for bankruptcy. On the contrary, if a company has a score less than 0.862 , then the company is predicted to have potential for bankruptcy.

\subsubsection{Ohlson's Model}

The next prediction model of bankruptcy was investigated by Ohlson (1980), which was inspired by previous study. Ohlson (1980) derives a bankruptcy prediction model as an alternative to Altman's Z score model. The study employs logistic regression to examine the probability of a firm being bankrupt or non-bankrupt for the period of 1970 - 1976 (Sayari, Naz and Can Simga Mugan, 2017). The Ohlson model is different from the previous study model because this model has 9 variables consisting of several financial ratios. Ohlson (1980: 117-118) formulates his calculation model as follows.

$\mathrm{O}=-1,32-0,407 \mathrm{X}_{1}+6,03 \mathrm{X}_{2}-1,43$ $\mathrm{X}_{3}+0,0757 \mathrm{X}_{4}-2,37 \mathrm{X}_{5}-1,83 \mathrm{ROA}+$ $0,285 \mathrm{X}_{6}-1,72 \mathrm{X}_{7}-0,521 \mathrm{X}_{8}$

Where :

$\mathrm{X}_{1}=\mathrm{Log}$ (total assets / GNP price-level index)

$\mathrm{X}_{2}=$ Total liabilities / total assets

$\mathrm{X}_{3}=$ Working capital $/$ total assets

$\mathrm{X}_{4}=$ Current liabilities / current assets

$\mathrm{X} 5=1$ if total liabilities $>$ total assets; 0

if otherwise

ROA $=$ Net income $/$ total assets

$\mathrm{X}_{6}=$ Cash flow from operations $/$ total liabilities

$\mathrm{X}_{7}=1$ if Net income is negative; 0 if otherwise
$\mathrm{X} 8=($ NIt - NIt-1) $/($ NIt + NIt-1)

The criteria of the scores obtained by a company from this Ohlson prediction model exceeds 0.38 by which the company is predicted to have potential for bankruptcy. On the contrary, if a company has a score of less than 0.38 then the company is not predicted to have the potential to experience bankruptcy.

\subsubsection{Zmijewski's Model}

Zmijewski (1984) used financial ratios that measured firm performance, leverage, and liquidity to develop his model. The ratios were not selected on a theoretical basis, but rather on the basis of their performance in prior studies (John Stephen Grice, Jr. and Michael T. Dugan, 2003). Zmijewski (1984) used random sampling techniques in his study, as in Ohlson's (1980) study. The statistical method used by Zmijewski (1984) is the same to that is used by Ohlson, the logit regression. Using this method, Zmijewski model (1984) is as follows:

$\mathrm{X}=-4.803-3.599 \mathrm{ROA}+5.406 \mathrm{X} 1-$ $1.000 \mathrm{X}_{2}$

Where:

ROA $=$ Net income / total assets

$\mathrm{X}_{1}=$ Total debt $/$ total assets

$\mathrm{X}_{2}=$ Current assets / current liabilities

The criteria of the scores obtained by a company from this prediction model Zmijewski exceeds 0 then the company is predicted to have potential for bankruptcy. On the contrary, if a company has a score less than 0 then the company is predicted to have no potential to experience bankruptcy.

\subsubsection{Grover's Model}

The Grover model was proposed by Jeffrey S. Grover. The Grover model is a model created by re-designing and recalculating the Altman Z-Score model. Grover in Prianthini and Sari (2014) produces the functions as follows:

G-Score $=1,650 \mathrm{X}_{1}+3,404 \mathrm{X}_{2}-0.01$ $\mathrm{ROA}+0,057$

Where :

$\mathrm{X} 1$ = Working capital / Total assets 
$\mathrm{X}_{2}=$ Earnings before interest and taxes /

Total assets

ROA = net income / total assets

The Grover model categorizes the company in a bankrupt state with a score less than or equal to -0.02 . While the value for companies categorized as nonbankrupt is more than or equal to 0.01 .
The following is the framework in this study which explains that this study compares the five models of bankruptcy analysis at PT. Asuransi Harta Aman Pratama, Tbk. :

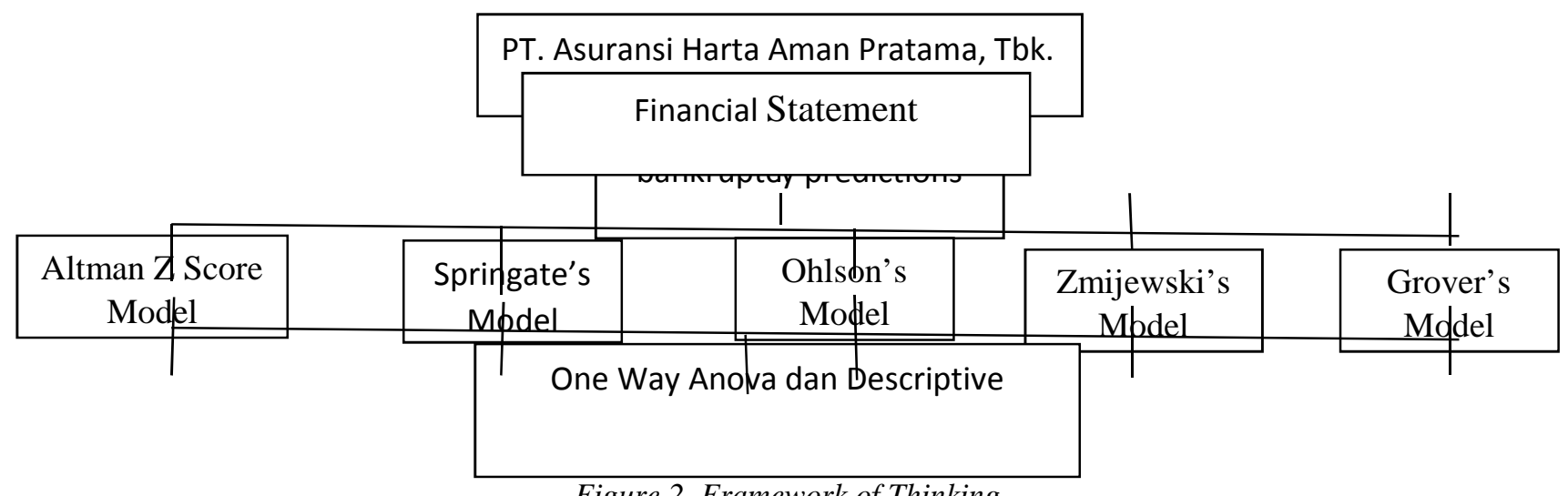

Figure 2 Framework of Thinking

\section{RESEARCH METHOD}

This study is a descriptive quantitative study. Descriptive study is a study conducted to determine and to explain the characteristics of variables studied in a certain situation. Objects in study is the financial statements of PT. Asuransi Harta Aman Pratama, Tbk. annual period 2012 2016.

Sources of data used in this study is secondary data which is obtained indirectly by studying the literature or documents related to the study. Study have been done by making PT. Asuransi Harta Aman Pratama, Tbk. as the studied company in the period 2012-2016 through financial statements books that have been obtained, and also can be accessed website www.idx.co.id.

Data collection method used in this study is documentation method.
Documentation method is a method of collecting data source from the investigated objects. The method of documentation in this study is to retrieve financial statements data of PT. Asuransi Harta Aman Pratama, Tbk.

\section{RESULT AND DISCUSSION}

The following is result of this study. There are he results of the score calculation of each prediction models of bankruptcy and result of test one way ANOVA

\subsection{The Results of The Score Calculation of Each Prediction Models Of Bankruptcy}

The results of the score calculation of each prediction models of bankruptcy is listed as follows: 
Table 1 The Results Of The Score Calculation Of Each Prediction Models Of Bankruptcy

\begin{tabular}{|c|c|c|c|c|c|c|c|c|c|c|}
\hline \multicolumn{11}{|c|}{ MODEL } \\
\hline \multirow[t]{2}{*}{ Tahun } & \multicolumn{2}{|c|}{ Altman Z } & \multicolumn{2}{|c|}{ Springate } & \multicolumn{2}{|c|}{ Ohlson } & \multicolumn{2}{|c|}{ Zmijewski } & \multicolumn{2}{|c|}{ Grover } \\
\hline & Score & result & Score & result 1 & Score & result & Score & result & Score & result \\
\hline 2012 & 2.0456 & Grey Area & 1.1994 & $\begin{array}{l}\text { Not } \\
\text { Bankrupt }\end{array}$ & -1.6058 & $\begin{array}{l}\text { Not } \\
\text { Bankrupt }\end{array}$ & -2.8172 & $\begin{array}{l}\text { Not } \\
\text { Bankrupt }\end{array}$ & 0.72558 & $\begin{array}{l}\text { Not } \\
\text { Bankrupt }\end{array}$ \\
\hline 2013 & 2.0738 & Grey Area & 1.2535 & $\begin{array}{l}\text { Not } \\
\text { Bankrupt }\end{array}$ & -2.4997 & $\begin{array}{l}\text { Not } \\
\text { Bankrupt }\end{array}$ & -2.8979 & $\begin{array}{l}\text { Not } \\
\text { Bankrupt }\end{array}$ & 0.75302 & $\begin{array}{l}\text { Not } \\
\text { Bankrupt }\end{array}$ \\
\hline 2014 & 2.0193 & Grey Area & 1.1833 & $\begin{array}{l}\text { Not } \\
\text { Bankrupt }\end{array}$ & -3.3467 & $\begin{array}{l}\text { Not } \\
\text { Bankrupt }\end{array}$ & -2.8570 & $\begin{array}{l}\text { Not } \\
\text { Bankrupt }\end{array}$ & 0.72636 & $\begin{array}{l}\text { Not } \\
\text { Bankrupt }\end{array}$ \\
\hline 2015 & 1.6787 & Bankrupt & 0.9306 & $\begin{array}{l}\text { Not } \\
\text { Bankrupt }\end{array}$ & -3.9686 & $\begin{array}{l}\text { Not } \\
\text { Bankrupt }\end{array}$ & -3.1349 & $\begin{array}{l}\text { Not } \\
\text { Bankrupt }\end{array}$ & 0.66336 & $\begin{array}{l}\text { Not } \\
\text { Bankrupt }\end{array}$ \\
\hline 2016 & 1.6371 & Bankrupt & 0.9130 & $\begin{array}{l}\text { Not } \\
\text { Bankrupt }\end{array}$ & -4.3580 & $\begin{array}{l}\text { Not } \\
\text { Bankrupt }\end{array}$ & -3.3981 & $\begin{array}{l}\text { Not } \\
\text { Bankrupt }\end{array}$ & 0.67868 & $\begin{array}{l}\text { Not } \\
\text { Bankrupt }\end{array}$ \\
\hline
\end{tabular}

Source : Self Proceed

Based on table 1, Almant ZScore predicts that the company is in grey area during the period of $2012-$ 2014 and bankrupt in $2015-2016$.
But the result of four other models (Springate, Ohlson, Zmijewski and Grover) showed that company does not bankrupt all year $2012-2016$.

\subsection{Result Test Of One Way ANOVA}

The results of One Way ANOVA test of all data to be analyzed in this study are as follow:

Tabel 2 One Way ANOVA Test Of Five Bankruptcy Prediction's Model On PT.Asuransi Harta Aman Pratama, Tbk. In Period 2012 - 2016

\begin{tabular}{|l|c|c|c|c|c|}
\hline \multicolumn{1}{|c|}{ Score } & $\begin{array}{c}\text { Sum Of } \\
\text { Squares }\end{array}$ & df & Mean Squares & F & Sig. \\
\hline Between groups & 115.677 & 4 & 28.919 & 105.026 & .000 \\
Within Groups & 5.507 & 20 & .275 & & \\
Total & 121.184 & 24 & & & \\
& & & & & \\
\hline
\end{tabular}

\section{Source : Self Proceed}

From the results of One Way ANOVA test, ANOVA sig value (p value) are obtained of 0.000 where $<0,05$ then it could be concluded that there is difference of bankruptcy level between Altman Z-score, Springate,
Ohlson, Zmijewski, and Grover on PT.Asuransi Harta Aman Pratama, Tbk. in the period of $2012-2016$.

Furthermore the results of Multiple Comparisons and Homogeneous Subsets are as follows: 
Table 3 Multiple Comparisons Of Five Bankruptcy Prediction's Model On PT.Asuransi Harta Aman Pratama, Tbk. In Period 2012 - 2016

\begin{tabular}{|c|c|c|c|c|c|c|c|}
\hline & \multirow[t]{2}{*}{ I (Model) } & \multirow[t]{2}{*}{$\mathbf{J}$ (model) } & \multirow{2}{*}{$\begin{array}{c}\text { Mean } \\
\text { diference } \\
(\mathrm{I}-\mathrm{J})\end{array}$} & \multirow[t]{2}{*}{ Std. Error } & \multirow[t]{2}{*}{ Sig. } & \multicolumn{2}{|c|}{$\begin{array}{c}95 \% \text { confidence } \\
\text { interval }\end{array}$} \\
\hline & & & & & & $\begin{array}{l}\text { Lower } \\
\text { bound }\end{array}$ & $\begin{array}{l}\text { Upper } \\
\text { bound }\end{array}$ \\
\hline \multirow[t]{20}{*}{ LSD } & $\begin{array}{l}\text { Altman Z- } \\
\text { Score }\end{array}$ & Springate & $.7950061 *$ & 0.3318748 & 0.026 & 0.102728 & 1.487285 \\
\hline & & Ohlson & $\begin{array}{r}5.0467759 \\
*\end{array}$ & 0.3318748 & 0.00 & 4.354497 & 5.739055 \\
\hline & & Grover & $\begin{array}{r}1.1815891 \\
*\end{array}$ & 0.3318748 & 0.02 & 0.489309 & 1.873866 \\
\hline & & Zmijewski & $\begin{array}{r}4.9120112 \\
*\end{array}$ & 0.3318748 & 0.00 & 4.219733 & 5.604290 \\
\hline & Springate & $\begin{array}{l}\text { Altman Z- } \\
\text { Score }\end{array}$ & $\begin{array}{r}- \\
0.7950061 \\
*\end{array}$ & 0.3318748 & 0.026 & -1.487285 & -0.102728 \\
\hline & & Ohlson & $\begin{array}{r}4.2517698 \\
*\end{array}$ & 0.3318748 & 0.00 & 3.559491 & 4.944048 \\
\hline & & Grover & 0.3865810 & 0.3318748 & 0.258 & -0.305698 & 1.078860 \\
\hline & & Zmijewski & $\begin{array}{r}4.1170051 \\
*\end{array}$ & 0.3318748 & 0.00 & 3.424726 & 4.809284 \\
\hline & Ohlson & $\begin{array}{l}\text { Altman Z- } \\
\text { Score }\end{array}$ & $\begin{array}{r}- \\
5.0467759 \\
*\end{array}$ & 0.3318748 & 0.00 & -5.739055 & -4.354497 \\
\hline & & Springate & $\begin{array}{r}- \\
4.2517698 \\
*\end{array}$ & 0.3318748 & 0.00 & -4.944048 & -3.559491 \\
\hline & & Grover & $\begin{array}{r}- \\
3.8651888 \\
*\end{array}$ & 0.3318748 & 0.00 & -4.557467 & -3.172910 \\
\hline & & Zmijewski & -0.1347647 & 0.3318748 & 0.689 & -0.827043 & 0.557514 \\
\hline & Grover & $\begin{array}{l}\text { Altman Z- } \\
\text { Score }\end{array}$ & $\begin{array}{r}- \\
1.1815871 \\
*\end{array}$ & 0.3318748 & 0.002 & -1.873866 & -0.489309 \\
\hline & & Springate & 0.3865810 & 0.3318748 & 0.258 & -1.078860 & 0.305698 \\
\hline & & Ohlson & $\begin{array}{r}3.8651888 \\
*\end{array}$ & 0.3318748 & 0.00 & 3.172910 & 4.557467 \\
\hline & & Zmijewski & $\begin{array}{r}3.7304241 \\
*\end{array}$ & 0.3318748 & 0.00 & 3.038145 & 4.422703 \\
\hline & Zmijewski & $\begin{array}{l}\text { Altman Z- } \\
\text { Score }\end{array}$ & $\begin{array}{r}- \\
4.9120112 \\
*\end{array}$ & 0.3318748 & 0.00 & -5.604290 & -4.219733 \\
\hline & & Springate & $\begin{array}{r}- \\
4.1170051 \\
*\end{array}$ & 0.3318748 & 0.00 & -4.809284 & -3.424726 \\
\hline & & Ohlson & 0.1347647 & 0.3318748 & 0.689 & -0.557514 & 0.827043 \\
\hline & & Grover & $\begin{array}{r}- \\
3.7304241 \\
*\end{array}$ & 0.3318748 & 0.000 & -4.422703 & -3.038145 \\
\hline
\end{tabular}

*The mean difference is significant at the 0.05 level

Source : Self Proceed 
Tabel 4 Homogeneous Subsets Of Five Bankruptcy Prediction's Model On PT.Asuransi Harta Aman Pratama, Tbk. In Period 2012 - 2016

\begin{tabular}{|l|l|r|r|r|r|}
\hline \multicolumn{2}{|c|}{ Model } & \multirow{2}{*}{ N } & \multicolumn{3}{|c|}{ Subset for alpha $=0.05$} \\
\cline { 3 - 6 } Duncan* & Ohlson & 5 & -3.155789 & & \multicolumn{1}{c|}{3} \\
\cline { 2 - 6 } & Zmijewski & 5 & -3.021024 & & \\
\cline { 2 - 6 } & Grover & 5 & & 0.709400 & \\
\cline { 2 - 6 } & Springate & 5 & & 1.095981 & 1.890987 \\
\cline { 2 - 6 } & Altman Z- & 5 & & & 1.000 \\
\hline
\end{tabular}

Means for groups in homogeneous subsets are displayed

*. Uses Harmonic Mean Sample Size $=5.000$

Source : Self Procesed

Based on the results of the analysis in Table 4.3 and Table 4.4, it can be concluded that the Ohlson model has similarities to the Zmijewski model, Grover model has in common with the Springate model, while the Almant Z model is different from the other four models.

\section{CONCLUSION}

Based on the results of the prediction analysis of bankruptcy using PT. Asuransi Harta Aman Pratama, Tbk. financial statements period 2012 - 2016, it can be concluded that:

1. The Almant $\mathrm{Z}$ model indicates that the company, during the period of

\section{REFERENCES}

Adriana, Azwir Nasir, dan Rusli. (2012), Analisis Prediksi Kebangkrutan Menggunakan Metode Springate pada Perusahaan Foods And

Altman, E. (1968), Financial ratios, discriminant analysis and the prediction of corporate bankruptcy. The Journal of Finance, 23, 589 - 609. doi:
$2012-2014$, is in the grey area, while in the period 2015 - 2016 is bankrupt.

2. The Springate, Ohlson, Zmijewski, and Grover models result notbankrupt indications, for the period 2012 - 2016.

3. There are differences among the five models of bankruptcy analysis (Altman Z-score, Springate, Ohlson Zmijewski, and Grover) used in this study.

4. Ohlson model has similarities to the Zmijewski model, Grover model has in common with the Springate model, while the model Almant $\mathrm{Z}$ is different to the other four models.

Beverages Yang Terdaftar di Bursa Efek Indonesia Periode 2006-2010, Skripsi, Fakultas Ekonomi Universitas Riau. 10.1111/j.1540-6261. 1968.tb00843

Annual Report PT. Asuransi Harta Aman Pratama, Tbk. 2012

Annual Report PT. Asuransi Harta Aman Pratama, Tbk. 2013 
Annual Report PT. Asuransi Harta Aman Pratama, Tbk. 2014

Annual Report PT. Asuransi Harta Aman Pratama, Tbk. 2015

Annual Report PT. Asuransi Harta Aman Pratama, Tbk. 2016

Antunes, Francisco, Bernardete Ribeiro,

Francisco Pereira. (2017). Probabilistic Modeling and Vizualization For Bankruptcy Prediction. http://dx.doi.org/10.1016/j.asoc. 2017.06.043. Applied Soft Computing 60. $831-843$.

Braunová, M., \& Jantošová, L. (2015). The Development Prediction of Financial and Economic Indicators of Hospitals Operating in Žilina Region. Management: Science and Education. EDIS - Editing Centre: University of Žilina. 1114.

Daniela, Rybárová, Braunová Mária, Jantošová Lucia. (2016). Analysis of the Construction Industry in the Slovak Republic by Bankruptcy Model. 3rd International Conference on New Challenges in Management and Organization: Organization and Leadership, 2 May 2016, Dubai, UAE.

El Khoury, Rim, and Al Beaïno, Roy. (2014).

Classifying

Manufacturing Firms in

Lebanon: An Application of Altman's Model. 2nd World Conference On Business, Economics And Management -WCBEM 2013.

Gamayuni, Rindu Rika. (2011), Analisis Ketepatan Model Altman Sebagai Alat untuk Memprediksi Kebangkrutan (Studi Empiris pada Perusahaan Manufaktur di BEI). Jurnal Akuntansi dan Keuangan, Vol 16 No.2, h. 176-190.

http://ekonomi.metrotvnews.com/read/2 016/03/01/492153/aauipertumbuhan-premi-asuransiumum-jeblok (accessed on $1^{\text {st }}$ February, 2018) http://www.neraca.co.id/article/66260/p ertumbuhan-premi-asuransianjlok (accessed on $1^{\text {st }}$ February, 2018)

I. Popchev, and I. Radeva. (2004). An Investment Preference Under Incomplete Data. IFAC DECOM-TT 2004. Automatic Systems for Building the Infrastructure in Developing Countries October 3 - 5, 2004 Bansko, Bulgaria.

John Stephen Grice, Jr. and Michael T. Dugan. (2003). Re-Estimations Of The Zmijewski And Ohlson Bankruptcy Prediction Models. Advances in Accounting Volume 20, 2003, Pages 77-93

Kusumo, Willyanto Tirto. (2002). Analisis Rasio-Rasio Keuangan Sebagai Indikator Dalam Memprediksi Potensi Kebangkrutan Perbankan Di Indonesia. Thesis. Program Studi Magister Akuntansi : Universitas Diponegoro.

Ohlson, J. (1980). Financial Ratios and The Probabilistic Prediction of Bankruptcy. Journal of Accounting Research, Vol. 18, No. 1, page 109131. Retrieved from Jstor Journal.

Prianthini, N. M dan Sari, R. M. (2014). Prediksi Kebangkrutan dengan Model Grover, Altman Z-Score, Springate, dan Zmijewski pada Perusahaan Food and Beverage di Bursa Efek Indonesia. EJurnal Akuntansi Universitas Udayana 5.2 (2013): 417435. Retrieved from Scholarly Articles Journal.

Putra, Ivan Gumilar Sambas, and Rahma Septiani. (2016). Analisis Perbandingan Model Zmijewski dan Grover Pada Perusahaan Semen Di Bei 2008-2014. JURNAL RISET AKUNTANSI DAN KEUANGAN, 4 (3), 2016, 1143-1154.

Sayari, Naz and Can Simga Mugan. (2017). Industry Spesific Financial Distress Modeling. 
BRQ Business Research

Quarterly (2017) 20. 45 - 62

Springate, Gordon L. V. (1978).

Predicting the Possibility of

Failure in a Canadian Firm.

MBA Research Project Simon

Fraser University: unpublished.

Suwarsono. (2000). Manajemen

Strategik, Konsep dan Kasus.

Yogyakarta: UPPAMP KPN 